\title{
Notes
}

\section{Discrimination in the Coverage of}

\section{Retirement Plans}

Under the Internal Revenue Code, retirement plans with qualified status generate substantial tax benefits for employees and employers alike. ${ }^{1}$ Of the many sections that determine qualification, section $410(b)(1)$ addresses inequalities in the coverage of retirement plans. To limit disparities in coverage based on income, the section requires that coverage not "be discriminatory in favor of . . . officers, shareholders, or highly compensated [employees]."2

In assessing whether retirement plans violate this section, government officials often apply vague tests that have been the source of considerable expense to employers and the government itself. The tests employ rough, indirect measures of inequality and hence cannot fully serve the purpose of the section. This Note proposes a clear measure of inequality with intuitive appeal, the Gini coefficient, which would form the basis of a new test. Under such a test, the Internal Revenue Service (IRS) would reject any plan whose Gini coefficient exceeded a predetermined maximum. The test would thus set clear limits on income-related discrimination in coverage. With minor adjustments, the test could also limit other forms of inequality that occur in retirement plans, such as discrimination in vesting.

\section{Current Methods of Preventing Discriminatory Coverage}

By enacting the predecessor to section $410(b)(1)$, Congress sought to extend the coverage of retirement plans to all classes of taxpaying workers, in roughly equal proportions. Responding to other concerns, however, Congress permitted some deviation from such a broadly egalitarian extension of coverage. The IRS was assigned the responsi-

1. The value of tax benefits generated by all qualified plans was $\$ 11.335$ billion in $1979, \$ 9.940$ billion in 1978 , and is estimated to be $\$ 12.925$ billion in 1980 . B. BrTTKER \& L. StOne, FeDERAL Income TAXation 32 (5th ed. 1980).

2. I.R.C. $\S 410(\mathrm{~b})(\mathrm{I})(\mathrm{B})$. 
bility of determining how much deviation was excessive, ${ }^{3}$ but has performed this task without great success.

\section{A. Favorable Tax Treatment for Nondiscriminatory Coverage}

For some time, the Internal Revenue Code has granted certain tax benefits to those retirement plans with qualified status. ${ }^{4}$ If a plan is qualified, the employer sponsoring it can deduct contributions to it as a business expense. ${ }^{5}$ Participating employees can exclude from their taxable income the employer's contributions and the earnings on the plan's assets, until those sums are actually distributed to the employees. ${ }^{6}$ At the death of an employee, payments to beneficiaries out of the employer's contributions can be excluded from the decedent's gross estate and thus are not subject to estate taxes.?

Before 1942, a plan could qualify for these tax advantages if it was established for the exclusive benefit of "some or all of the [company's] employees." 8 As a result, a few highly paid employees of a company, by creating a plan that covered only themselves, could defer considerable amounts of taxable income for long periods of time. As early as 1937, the Treasury Department argued forcefully that the benefit of deferral should not be appropriated solely by the highly paid, but rather should be extended to workers at many levels of income. $^{9}$

3. Id. (Secretary of Treasury is charged with determining whether plan is discriminatory).

4. One commentator on pension plans has described qualified status as being "highly prized and earnestly sought." D. McGilr, Fundamentals of Private Pensions 25 (3d ed. 1975). In 1921, Congress enacted legislation that for the first time gave favorable tax treatment to certain employees' trusts. Revenue Act of 1921, ch. 136, § 219(f), 42 Stat. 227 (current version at I.R.C. $\$ \$ 401-404,501$ ) (trust created by employer as part of stock bonus or profit-sharing plan for exclusive benefit of some or all employees is not taxable; distributions from trust are taxable at time distributed). The Act did not mention pension plans or pension trusts, but in 1926 Congress made $\$$ 219(f) explicitly applicable to them. Revenue Act of 1926, ch. 27, $\$ 219(\mathrm{f}), 44$ Stat. 33 (current version at I.R.C. $\S \S 401.404,501)$.

5. I.R.C. § 404(a).

6. Id. $\$ 402(a)(1)$ (amount actually distributed or made available to employee is taxable to employee in year distributed). Earnings on the plan's assets are not taxable to the plan either. Id. $\$ 501$ (a) (organization described in I.R.C. $\$ 401(a)-$ that is, qualified retirement plan-is exempt from taxation).

7. Id. $\$ 2039$ (c).

8. Revenue Act of 1921, ch. 136, $\S 219(f), 42$ Stat. 227 (current version at I.R.C. $\S \S 401$ 404, 501). The Revenue Act of 1928, ch. 852, $\S 165,45$ Stat. 791 (current version at I.R.C. $\$ \S 401-404,501)$ adopted this section without change.

9. In a letter to Congress dated May 29, 1937, the Secretary of the Treasury, Henry Morgenthau, Jr., stated:

For 10 years the revenue acts have sought to encourage pension trusts for aged employees by providing corporations with a special deduction on account of con. 
In 1942, Congress came to share the Department's concern. ${ }^{10}$ Income tax rates and the number of wage earners paying income tax had increased sharply. ${ }^{11}$ Workers in many income brackets could therefore legitimately insist on an opportunity to defer taxable income through retirement plans. In response, Congress enacted the forerunner of section $410(b)(1)$, section $165(a)$ (3) of the 1939 Code, to "insure that stock bonus, pension, or profit-sharing plans are operated for the welfare of employees in general, and to prevent the trust device from being used for the benefit of shareholders, officials, or highly paid employees."12 To give substance to those goals, section 165(a)(3) provided that a plan would not receive qualified status if the Commissioner of Internal Revenue judged the plan's coverage to be discriminatory. ${ }^{13}$ Through these legislative actions, Congress sought to extend coverage to all classes of taxpaying workers.

Broadening the coverage of private retirement plans served an additional purpose. In 1935, Congress created the social security system to "insure not merely subsistence but some of the comforts of life" for a broad range of retiring employees. ${ }^{14}$ Unfortunately, through-

tributions thereto and exempting the trust itself from tax. Recently this exemption has been twisted into a means of tax avoidance by the creation of pension trusts which include as beneficiaries only small groups of officers and directors who are in the high-income brackets. In this fashion high-salaried officers seek to provide themselves with generous retiring allowances ....

81 Conc. REc. 5125 (1937). Introducing Secretary Morgenthau's letter in the Congressional Record, President Franklin D. Roosevelt wrote: "We face a challenge to the power of the Government to collect uniformly, fairly, and without discrimination taxes based on statutes adopted by the Congress." Id. at 5124 .

In 1942, the Secretary of the Treasury's Special Tax Adviser, Randolph E. Paul, testified before the House Committee on Ways and Means. He proposed that pension trusts should not be exempted from tax unless they covered either $70 \%$ of all full-time, nonseasonal employees or a group of employees qualifying under a classification found to be nondiscriminatory by the Commissioner. Revenue Revision of 1942: Hearings Before the House Comm. on Ways and Means (pt. 1), 77th Cong., Ist Sess. 87 (1942).

10. See N. Ture, The future of Private Pension Plans 34 (1976) (discrimination against wage employees created legislative concern).

11. Id. ("II]ncome tax rates shot up in the early 1940's, . . . [w]ith a vastly larger number and proportion of wage employees subject to tax ....")

12. H.R. REP. No. 2339, 77th Cong., 2d Sess. 103-04 (1942).

13. Under subsection (B), a trust forming part of a stock bonus, pension, or profitsharing plan of an employer for the exclusive benefit of his employees was not taxable if the plan benefited "such employees as qualify under a classification set up by the employer and found by the Commissioner not to be discriminatory in favor of employees who are officers, shareholders, persons whose principal duties consist in supervising the work of other employees, or highly compensated employees . . . ." Revenue Act of 1942 , ch. $619, \S 162$ (a), 56 Stat. 798 (adding $\S 165(a)(3)(B)$ to Int. Rev. Code of 1939) (current version at I.R.C. $\$ 410(\mathrm{~b})(\mathrm{I})(\mathrm{B})$ ).

14. H.R. REP. No. 615, 74th Cong., Ist Sess. 5 (1935); see S. REP. No. 628, 74th Cong., Ist Sess. 7 (1985) (program's goal should be to provide "something more than merely reasonable subsistence"). 
out its years of operation, the benefits flowing to many recipients under the program have not been sufficient to provide even for subsistence. ${ }^{15}$ Since the commencement of the program, private retirement plans have been viewed as a supplement that can compensate for the deficiencies of the social security system. ${ }^{16}$ To be effective in this way, however, private retirement plans must provide extensive coverage for the country's workers.

Unfortunately, the coverage of private plans continues to be limited. In 1977, private coverage reached only about one-half of the private work force, and workers with lower incomes tended to receive less coverage. ${ }^{17}$ In contrast, the social security system covered nine of every ten people who were at least 65 , in almost every class of income.18 If private plans are to make up for deficiencies in social security that persist today, they must cover employees in every class of income.

Although congressional policy has generally sought to include all income classes in private retirement plans, Congress permits the exclusion of some employees by certain classifications not based on income. ${ }^{19}$ In its report on section 165(a)(3), the House Ways and Means

15. See M. Bernstein, The Future of Private Pensions 189-90 (1964) (in early $1960 \mathrm{~s}$ social security benefits fell short of adequacy as measured by the Bureau of Labor Statistics (B.L.S.) budget; average couple's social security benefits amounted to $\$ 1,640$ a year, which was $54 \%$ of $\$ 3,000$ B.L.S. budget line); P. BRINKER, Economic INSEcuRITY ANd Social Security 72-73 (1968) (Old Age Insurance was inadequate from 1940 to 1949); P. Brinker \& J. Klos, Poverty, Manpower, and Social. Security 112, 113 (1976) (low level of benefits has been a problem since inception of social security program; in recent years, "[b]enefit amounts alone are still ordinarily not enough to raise many workers above the poverty level .... If benefits are termed adequate for those above the poverty level, and inadequate for those below, a substantial social problem still exists involving 3.3 million aged persons."); J. Pechman, H. Aaron, \& M. Taussig, Social Security: PerSPECTIVES FOR REFORM 91 (1968) (in mid-1960s minimum benefit was $42 \%$ of poverty threshold as officially defined by Social Security Administration for single retired worker and $50 \%$ for married couple).

16. See M. Bernstein, supra note 15, at 190 (private plans should be used to supplement inadequate social security); D. MCGill, supra note 4, at 135 (social role of private pension plans is to supplement "the old-age insurance benefits provided under the Social Security System . . . for a broad segment of the labor force"); Seidman, Concepts of Balance Between Social Security (OASDI) and Private Pension Benefits, in Soctal Security and Private Pension Plins 81 (D. McGill ed. 1977) (referring to "the necessity to turn to private pension plans to supplement inadequate social security payments"). See also P. BRINker \& J. Klos, supra note 15, at 113 (need for larger pensions became so urgent that number of labor unions in 1949 and 1950 concentrated on obtaining larger pensions as their primary issue in bargaining negotiations); Seidman, supra, at 80 (unions negotiated private pension plans not because they considered plans superior to social security program, but because they found that retirement income paid by social security was grossly inadequate to meet needs of their members, and were unable to get Congress to improve social security benefits sufficiently).

17. Seidman, supra note 16 , at 79 .

18. Id.

19. I.R.C. $\S 401(a)(5)$ provides: “A classification shall not be considered discriminatory 
Committee stated that a plan could be confined to the employees of certain designated departments, to employees who had reached designated ages or who had been in the company's employment for a designated number of years, or to clerical or salaried employees as opposed to employees paid on an hourly basis. ${ }^{20}$ The sole requirement specified by the Committee was that the classifications not be discriminatory by income. ${ }^{21}$

A plan adopting a nonincome classification, however, unavoidably generates disproportionate coverage for some classes of income. Employees who have not reached a specified age or who have worked less than a designated period of time, for example, tend to receive lower incomes than employees who have met those age or service requirements for coverage. ${ }^{22}$ A classification based on age or years of

within the meaning of . . . Section $410(b)$. . . merely because it is limited to salaried or clerical employees." In 1942, the Internal Revenue Code had an identical provision. Revenue Act of 1942, ch. 619, $\S 162(\mathrm{a}), 56$ Stat. 798 (adding $\S 165(\mathrm{a})(5)$ to Int. Rev. Code of 1939) (current version at I.R.C. $\$ 401(a)(5)$ ). I.R.C. $\$ 410(a)$ permits certain classifications based on age or service.

I.R.C. $\S 401$ (a)(5) also provides: "A classification shall not be considered discriminatory within the meaning of . . . Section $410(\mathrm{~b})$. . . merely because it excludes employees the whole of whose remuneration constitutes 'wages' under section 3121(a)(1) (relating to the Federal Insurance Contributions Act) ...." In 1942, the Internal Revenue Code had a provision that was essentially the same. Revenue Act of 1942, ch. 619, $\S$ 162(a), 56 Stat. 798 (adding $§ 165(a)(5)$ to Int. Rev. Code of 1939) (current version at I.R.C. $\S 401(a)(5))$. This provision permits companies to exclude workers below the social security wage limit.

In practice, companies seldom set up such classifications based on income; for if they do, they must comply with strict requirements, imposed by the IRS, that place a low ceiling on the benefits that participants may receive. If the plan's benefits are based on annual compensation averaged over a minimum of five consecutive years, the rate at which retirement benefits are provided cannot exceed $1 \%$ and can apply only to average compensation in excess of the wage base. If the plan bases an employee's benefits on his actual compensation from year to year, the rate at which retirement benefits are provided cannot exceed $1.4 \%$ of the employee's compensation in excess of the applicable wage base. Rev. Rul. 71-446, 1971-2 C.B. 187, 190. To assure a worthwhile benefit for employees receiving more than the social security wage limit, most companies have chosen not to set up such a classification by income, regardless of whether the retirement plan is a pension plan or a profit-sharing plan. See D. McGill, Fundamentals of Private Pensions 191.92 (4th ed. 1979) (pension plans that do not condition coverage on employee's level of income are "in much more use than the pure excess plan," which does set up classification by income); $i d$. at 523 ("[W]ith respect to coverage ... relatively few profit sharing plans are integrated with social security ... [meaning] that those employees earning less than the social security wage base (or some other stipulated amount) will not be excluded from coverage under the plan.")

20. H.R. REP. No. 2333, supra note 12 , at 103-04. Companies sponsoring retirement plans often adopt age and service requirements to lower the surrender charges caused by the high turnover of younger employees with short service. See Haskins \& SELIS, THE Pension System in the United States 26 (1964); Buck, Features of Present-Day Plans, in Pensions and Profit Sharing 17 (3d ed. 1964).

21. H.R. REP. No. 2333, supra note 12 , at 103.04.

22. See M. BERNSTEIN, supra note 15, at 176-86. 
service is therefore likely to provide less coverage for workers in lower classes of income. ${ }^{23}$

A retirement plan under which no single income class is given a disproportionate share of the available coverage might be said to provide "strict equality" in its coverage. Strict equality would ensure that the plan did not discriminate-that it did not offer special opportunities to defer income or otherwise provide preferential treatment to one income class over another. Yet, by allowing certain nonincome classifications, Congress intended to permit some deviation from strict equality in coverage. Congress did not specify how much deviation would be permissible, but left that judgment to the Commissioner of Internal Revenue. ${ }^{24}$

\section{B. Enforcement of Congressional Policy}

Since 1942, the IRS has developed many tests to determine whether a plan's inequality in coverage is intolerably high, and uses any number of them to assess the coverage of a retirement plan. These tests fall into two categories. The first category consists of tests derived directly from the statutory phrase "officers, shareholders, or highly compensated." 25 Under these tests, the IRS chooses a level of income, which can vary from company to company, and defines those employees above that level as "highly compensated" and those below it as "lower paid." 26 The IRS then assesses the plan's coverage by cal-

23. See id.

24. Revenue Act of 1942, ch. 619, $\$ 162$ (a), 56 Stat. 798 (adding $\S 165(a)(3)(B)$ to Int. Rev. Code of 1939) (current version at I.R.C. $\$ 410(\mathrm{~b})(1)(B)$ ). I.R.C. $\$ 410(\mathrm{~b})(1)(\mathrm{A})$ (originally enacted as Revenue Act of 1942 , ch. $619, \S 162(a), 56$ Stat. 798 , which added $\S$ $165(a)(3)(A)$ to Int. Rev. Code of 1939) does establish a mechanical "safe harbor" test under which a plan may satisfy the requirement prohibiting discriminatory coverage. Subsection (A) requires the coverage of $70 \%$ of all employees or, in the case of a contributory plan, $80 \%$ of eligible employees if $70 \%$ of all employees are eligible. If a plan does not meet the stringent requirements of subsection (A), it is subject to examination under subsection (B). See Internal Revenue Service, Training Manual Retirement Plans 5-25 (1975). Because of the stringency of subsection (A), a majority of plans fail to satisfy its requirements and become subject to examination under subsection (B). See Interview with Attorney practicing in the field of retirement plans, in California (Nov. 3, 1980) (notes on file with Yale Law Journal).

25. I.R.C. $\$ 410(\mathrm{~b})(1)(B)$. Under the original legislation, a plan also could not discriminate in favor of "persons whose principal duties consist in supervising the work of other employees." Revenue Act of 1942, ch. 619, $\$ 162(a), 56$ Stat. 798 (adding $\S$ 165(a)(3)(B) to Int. Rev. Code of 1939) (current version at I.R.C. $\$ 410$ (b)(1)(B)). Until 1974, when this phrase was deleted, see Retirement Plan Amendments of 1974, Pub. $L$. No. 93-406, $\S 1011,88$ Stat. 898 , tests in the first category often made reference to "supervisors" or "supervisory personnel."

26. See Rev. Rul. 56-497, 1956-2 C.B. 284, 286 (“The terms 'highly compensated' and 'lower compensated' are relative, and the distinction between them must be based upon the circumstances of each case."); cf. Treas. Reg. $\$ 1.410(\mathrm{~b})-1(\mathrm{~d})(\mathrm{l})$ (1977) (classification of employec as highly compensated for section $410(\mathrm{~b})(\mathrm{l})(\mathrm{B})$ made on basis of facts and circumstances of each case, taking into account employee's compensation and compensa- 
culating proportions selected somewhat arbitrarily from a list of several possibilities: the proportion of participants who are highly compensated; the proportion of participants who are officers or shareholders; the proportion of participants who are officers, shareholders, or highly compensated employees; and the proportion of highly compensated employees who are participants. If the chosen proportions for a given plan are deemed too high, the IRS finds the plan to be discriminatory. ${ }^{27}$

"Cross section tests" form the second category. Under these tests, the IRS constructs a table showing the distributions of plan participants and of excluded employees, by various income brackets. It then looks at the number of participants who fall into brackets that also contain excluded employees. If the number of participants is unreasonably small, the IRS finds the plan to be discriminatory. ${ }^{28}$ Oc-

tion paid other employees by employer). The courts have approved this method of defining highly compensated employees. See, e.g., Commissioner v. Pepsi-Cola Niagara Bottling Corp., 399 F.2d 390, 393 (2d Cir. 1968) ("We cannot say that in thus reading 'highly' as 'more highly' [in Rev. Rul. 56-497, 1956-2 C.B. 284] . . . the Commissioner went beyond the powers Congress conferred upon him ....")

27. See, e.g., Rev. Rul. 74-256, 1974-1 C.B. 94, 95 (plan found discriminatory when "two of the eight participants are officer-shareholders" and "three of the eight participants are highly compensated"); Rev. Rul. 74-255, 1974-1 C.B. 93, 94 (plan found discriminatory when "four of the seven participants are shareholders"); Rev. Rul. 74-141, 1974-1 C.B. 93, 93 (plan found discriminatory when "[e]ach of the [two] participants owns 50 percent of the outstanding stock of the company"); Rev. Rul. 73-283, 1978-2 C.B. 133, 133-34 (plan found discriminatory when "[all] five [participants] are either officers or supervisors and four of them are also shareholders" and "all the participants in the plan are officers, shareholders, or supervisors and are highly compensated"); Rev. Rul. 66-13, 1966-1 C.B. 73, 74 (plan found discriminatory when "[t]he two participants are officers and supervisors and each is compensated at a substantially higher rate than" the other employees); Temp. Treas. Reg. $\$ 11.410(b)-(1)(d)(2)(1975)$ (determination of discrimination in favor of officers, shareholders, or highly compensated employees is based in part on ratio "of such employees benefited by the plan to all employees benefited by the plan").

28. See, e.g., Rev. Rul. 74-256, 1974-1 C.B. 94, 95; Rev. Rul. 74-255, 1974-1 C.B. 93, 94; Rev. Rul. 70-200, 1970-1 C.B. 101, 101. Revenue Rulings 70-200 and 74-256 illustrate the cross-section test. Revenue Ruling 70-200 evaluates a plan that clearly passed the test, while Revenue Ruling $74-256$ evaluates a plan that clearly failed. Revenue Ruling 70200 offers the following distribution of participants and excluded employees:

Compensation Range
$\$ 25,001$ to $\$ 30,000$
$\$ 20,001$ to $\$ 25,000$
$\$ 15,001$ to $\$ 20,000$
$\$ 12,501$ to $\$ 15,000$
$\$ 10,001$ to $\$ 12,500$
$\$ 7,501$ to $\$ 10,000$
$\$ 5,001$ to $\$ 7,500$
$\$ 2,500$ to $\$ 5,000$
ToTAL

Excluded Employees
0
0
18
37
38
11
4
2
110

Participants
4
0
7
8
12
3
5
1
$\frac{40}{10}$

The above plan passed: "Twenty-two of the 40 plan participants are officer-shareholders, shareholder-supervisors, or supervisors (persons in whose favor discrimination is pro- 
casionally, the IRS insists that the plan include employees of lower and middle income brackets in more than nominal numbers or that the plan cover employees in all compensation ranges. ${ }^{28}$

Generally, the courts have sustained the actions of the IRS. Often employing the same or similar tests, the courts have approved the reasoning of the IRS as well. ${ }^{30}$ Both categories of tests, therefore, have received judicial ratification.

hibited). However, the compensation of all but 4 of the 40 participants is substantially the same as that of the excluded hourly-paid employees." Rev. Rul. 70-200, 1970-1 C.B. $101,101$.

Revenue Ruling 74-256 offers the following distributions:

Compensation Range
Above $\$ 25,000$
$\$ 20,001$ to $\$ 25,000$
$\$ 15,001$ to $\$ 20,000$
$\$ 12,501$ to $\$ 15,000$
$\$ 10,001$ to $\$ 12,500$
$\$ 9,001$ to $\$ 10,000$
$\$ 8,001$ to $\$ 9,000$
$\$ 7,001$ to $\$ 8,000$
$\$ 6,001$ to $\$ 7,000$
$\$ 5,001$ to $\$ 6,000$
$\$ 5,000$ and below
TOTAL

Excluded Employees

$\begin{array}{r}0 \\ 0 \\ 0 \\ 0 \\ 3 \\ 16 \\ 18 \\ 5 \\ 9 \\ 0 \\ 4 \\ \hline 55\end{array}$

Participants
2
1
0
2
0
0
0
0
0
0
$\frac{3}{8}$

The plan failed: "Two of the eight participants are officer-shareholders. Three of the eight participants are highly compensated in relation to the excluded employees .... [In Rev. Rul. 70-200], unlike this case, the compensation of nearly all the participants was substantially the same as that of the excluded employees." Rev. Rul. 74-256, 1974-1 C.B. 94, 95. Note that in both Revenue Rulings, the IRS drew from tests in the first category in addition to those in the second category.

29. For example, in Revenue Ruling 70-200, see note 28 supra, the plan also passed because the plan "covers employees in all compensation ranges; those in the middle and lower brackets are covered in more than nominal numbers." Rev. Rul. 70-200, 1970-1 C.B. 101, 101. In Revenue Ruling 74-256, see note 28 supra, the plan also failed because "the plan does not cover employees in all compensation ranges." Rev. Rul. 74-256, 1974-1 C.B. 94, 95 .

30. The courts have approved and used tests in the first category. See, e.g., Container Servs. Co. v. United States, 478 F.2d 770, 771 (6th Cir. 1973) (court, like Commissioner, held that profit-sharing plan was discriminatory because "[e]ach year four of the five eligible employees were either officers or supervisors"); Cornell-Young Co. v. United States, 469 F.2d 1318, 1324 (5th Cir. 1972) (supporting Commissioner's finding, court held plan to be discriminatory because "[o]f these 7 [covered by the plan], 6 were either officers, shareholders, supervisors, or highly paid employees"); John Duguid \& Sons v. United States, 278 F. Supp. 101, 105 (N.D.N.Y. 1967) (court affirmed Commissioner's finding that plan was discriminatory because all three participants were either owners or supervisor); Pulver Roofing Co. v. Commissioner, 70 T.C. 1001, 1009-10 (1978) (court, like Commissioner, found plan discriminatory because in three of four years "at least 75 percent of the plan participants were officers and supervisory employees, and, in the remaining year, 50 percent of the participants were in those categories"); Babst Servs., Inc. v. Commissioner, 67 T.C. 131, 138-39 (1976) (Commissioner did not err in finding discriminatory plan in which three of four employees eligible to participate were highly compensated employees, officers, or shareholders).

On some occasions, the courts in reviewing the decisions of the IRS have used the 


\section{Rationale for a Numerical Test of Discriminatory Coverage}

Although they can be used to evaluate the coverage of any retirement plan, these tests suffer from two major difficulties. First, they are vague, and consequently they generate considerable expense, permit inconsistent decisions, and deter some companies from setting up retirement plans altogether. Second, the tests do not comprehensively address inequalities in coverage based on income. A clear measure of inequality with intuitive appeal-the Gini coefficient, for exampleshould therefore form the basis of a new test.

\section{A. Deficiencies in th: Form of Current Tests}

The tests currently used by the IRS are vague. The IRS has failed to promulgate any standards for applying its various tests, and it seldom notifies the plan's sponsors of the tests it intends to use in judging the plan. This vagueness has a number of disadvantages. The process of negotiation between the IRS and a company seeking to qualify its plan tends to be extended, and the costs of negotiation are generally substantial for both parties. ${ }^{31}$ Because negotiations over

converses of the tests enumerated above, see pp. 822-23 supra: the proportion of lower paid employees who are participants, the proportion of employees other than officers and shareholders who are participants, or the proportion of employees other than officers, shareholders, and the highly paid who are participants. Plans have failed these tests if their proportions were too low. See, e.g., Loevsky v. Commissioner, 471 F.2d 1178, 1180 (3d Cir. 1973) (plan failed because "[a]ll employees who were members of the prohibited group [officers, shareholders, and highly compensated employees] were among those covered" while 5\% of other members of work force were included); Pulver Roofing Co. v. Commissioner, 70 T.C. 1001, 1010 (1978) (plan failed because "in each of the years, 100 percent of petitioner's officers participated in the plan, whereas less than 3 percent of the other employees were covered in 1970, 1971, and 1973 and approximately 8.5 percent were covered in 1972").

The courts have also approved and used tests in the second category. See, e.g., Commissioner v. Pepsi-Cola Niagara Bottling Corp., 399 F.2d 390, 394 (2d Cir. 1968) (court, like Commissioner, found discriminatory plan in which all participants received more income than any of excluded employees); King v. United States, 376 F. Supp. 1313, 1319 (D. Neb. 1974) (sustaining Commissioner, court found discriminatory plan that failed to cover employees in middle and lower compensation ranges).

31. Small companies incur substantial negotiation costs because of the vagueness of current tests of discriminatory coverage. For the small business, the cost of hiring a lawyer and an accountant to present a proposed plan to the IRS is significant. Also considerable is the cost of appealing to the national office of the IRS from the district office; such an appeal becomes necessary if negotiations over the vague standards break down at the district office. The small company incurs an additional cost when a proposed plan is rejected by the IRS and must be revised and resubmitted. Interview with Paul Jackson, The Wyatt Company, in Washington, D.C. (Nov. 3, 1980) (notes on file with Yale Law Journal).

The vagueness of current tests generates significant costs for larger firms as well. A serious problem arises when a large company acquires a smaller company with no retirement plan or with a plan somewhat different from that of the acquirer. Under section 414 , if an acquiring company owns at least an $80 \%$ interest in a subsidiary so that a 
vague standards are more likely to break down, the vagueness of the current tests increases the likelihood of costly litigation. Even before negotiations begin, lack of certainty can complicate the legal planning of a company sponsoring a plan. ${ }^{32}$ The considerable expenses that arise from uncertain standards may deter smaller companies from setting up retirement plans altogether. ${ }^{33}$ Finally, because the IRS annually makes some ten thousand determinations on the qualification of plans, ${ }^{34}$ the vagueness of current tests increases the probability that at least some of its decisions are inconsistent with others. ${ }^{35}$

In addition, the current tests do not fully implement congressional policy on inequalities in coverage. All the tests in the first category, which are concerned explicitly with compensation, divide employees into only two groups, the highly paid and the lower paid, and are not sensitive to the coverage of various classes within the lower paid. As a result, the tests do not measure precisely a plan's deviation from equality in coverage. A similar problem afflicts the cross-section test. Although it looks at more classes of income and sometimes requires that more than nominal numbers of employees be covered in several income classes, it does not consider the total number of employees in each of those classes. Hence, the test does not look at the proportion of all employees that a given class contains; it does not consider

"commonly controlled group" is thereby formed, the IRS must evaluate the coverage of all employees in the parent and the subsidiary together. I.R.C. $\$ 414(\mathrm{~b})$. If the controlled group submits its proposal to the IRS and the proposal is rejected under the currently vague standards, the cost of revision and resubmission is great. Interview with Paul Jackson, supra. The legal, actuarial, and administrative costs are great when a controlled group negotiates with the IRS to meet the tests of discriminatory coverage. Interview with Attorney practicing in the field of retirement plans, supra note 24.

32. The current tests of discriminatory coverage create significant planning costs for the controlled group of large and small companies. See note 31 supra. The controlled group, its actuaries, and its lawyers spend considerable time compiling data on the coverage of the group's employees and using that data to prepare the group's presentation to the IRS. Vagueness is responsible for significant costs in preparing the presentation because, under the vague tests, a variety of arguments are available to the controlled group when it makes its application to the IRS. Interview with Attorney practicing in the field of retirement plans, stpra note 24.

33. Interview with Paul Jackson, supra note 31.

34. M. BERNSTEIN, supra note 15 , at 185 .

35. The vagueness in the current tests causes the decisions on discriminatory coverage to be inconsistent: standards vary considerably from district to district and even from reviewer to reviewer within a district. Interview with Chester Salkind, The American Society of Pension Actuaries, in Washington, D.C. (Nov. 4, 1980) (notes on file with Yale Law Journal). Further, plans that in one region pass the tests of discriminatory coverage might fail in another. Interview with Paul Jackson, supra note 31; Interview with Attorney practicing in the field of retirement plans, in Texas (Nov. 4, 1980) (notes on filc with Yale Law Journal). Some district directors and some local IRS agents are more lax than others in applying the tests of discriminatory coverage. Interview with Paul Jackson, supra note 31; Interview with Chester Salkind, supra; Interview with Attorney practicing in the field of retirement plans, supra note 24. 
the proportion of all coverage that the class receives; and it does not determine whether that class has a disproportionate share of the coverage available under the plan. ${ }^{30}$ In failing to measure inequality in coverage systematically, the tests cannot accurately set a maximum on the amount of inequality that will be tolerated.

A superior test would remedy these difficulties. Such a test would measure inequality directly and then place a limit on the inequality that would be permissible. It would substitute one test for the confusing variety of tests currently in use. Finally, a superior test would employ a numerical criterion ${ }^{37}-\mathrm{a}$ "brightline" standard, which would eliminate or significantly reduce many of the costs generated by the vagueness of current tests. ${ }^{38}$

\section{B. Proposed Measure of Inequality}

One possible basis for a superior test is a measure of inequality called the "Gini coefficient." 39 One of the traditional indices of economic disparity, ${ }^{40}$ the Gini coefficient has been used to measure

36. In addition, because the cross-section test allows the sponsoring company some discretion in the breakdown of income classes it reports, important infornfation about the inequality of a plan may not be disclosed to the IRS. Question 15K of Form 5300, the application form for the granting of qualified status, asks the sponsoring company for information to apply the tests under section $410(\mathrm{~b})(1)$. The question requires only that "the compensation brackets used must reflect the pay pattern of the employer." [1980] I Pens. \& Profit Sharing (P-H) If 24,178. Companies can to some extent alter the breakdown to persuade the IRS that they meet the tests of discriminatory coverage. In. terview with Attorney practicing in the field of retirement plans, supra note 24.

37. The IRS uses numerical tests to evaluate discrimination in other settings-for example, in assessing whether a plan's integration with Social Security is discriminatory. See Rev. Rul. 71-446, 1971-2 C.B. 187, 190.

38. See pp. 825-26 supra. A clear numerical standard would save many of the administrative, actuarial, and legal costs of planning and negotiation now generated by the vague tests. Interview with Attorney practicing in the field of retirement plans, supra note 31; Interview with Attorney practicing in the field of retirement plans, supra note 35 .

A numerical, or "brightline," test would insure that IRS rulings are consistent. See Note, A Spreading of Receipts Formula for Creating a Capital Gains/Ordinary Income Brightline: Contract Termination Payments and Business-Versus-Investment Assets, 87 YALE L.J. 729, 754 (1978) ("The advantages of mechanical, brightline tests are well known: they tend to be uniform in application, yiclding a high degree of consistency across cases and courts ...."); Interview with Chester Salkind, supra note 35; Interview with Attorney practicing in the field of retirement plans, supra note $\mathbf{3 5 .}$

39. The measure has also been called "Gini's Ratio of Concentration," Yntema, Measures of the Inequality in the Personal Distribution of Wealth or Income, $28 \mathrm{~J}$. AM. Statistical A. 423, 425 (1933), the "Gini coefficient of inequality," R. Allen, INDEX Numbers in Theory and Practice 218 (1975), and the "Coefficient of Concentration," Conrad, Redistribution Through Government Budgets in the United States, 1950, in Income Redistribution and Social. Policy 178, 242 (A. Peacock ed. 1954).

40. The Gini coefficient has been in use for at least sixty-five years: the Italian economist Corrado Gini introduced his measure in 1912. C. Gini, Variabicita E MutaBLITA 21-33 (1912). 


\section{inequality in the distribution of income, ${ }^{41}$ of consumption, ${ }^{42}$ and of wealth. ${ }^{43}$ It is defined to be one-half the relative mean difference of people's incomes-that is, one-half the average of the absolute values of differences between all pairs of income.44}

41. Economists using the Gini coefficient have measured inequality in the distribution of a nation's income and traced the changes in that inequality over time. See, e.g., H. Miller, Income Distribution in the United States 24-25 (1966) (Gini coefficients for United States in each year from 1947 to 1960); D. SeERs, The LevelLiNG of INCOMEs SINCE 1938, at 37.38 (1951) (comparing Gini coefficients for United Kingdom in 1938 and in 1947); Conrad, supra note 39, at 200 (comparing Gini coefficients for United States in 1938-39 and 1950); Goldsmith, Impact of the Income Tax on Socio-Economic Groups of Families in the United States, in Income AND WeALth: SERIES X 271 (C. Clark \& G. Stuvel eds. 1964) (comparing Gini coefficients for United States in 1929 and in 1959).

Other economists employing the Gini coefficient have measured inequality in the distribution of the world's income and have shown how little that inequality has diminished over time. See Andic \& Peacock, The International Distribution of Income, 1949 and 1957, 124 J. Royal Statistical Soc'y (SERIEs A) 206, 208 (1961) (comparing Gini coefficients computed on international distribution of income in 1949 and in 1957 and finding no significant change).

Similarly, economists have used the Gini coefficient to compare income inequality among different nations or among different states within a nation, at one time. See UNITED NATIONS ECONOMIC COMmission for EUROPE, Incomes in POSTWAR EUROpE ch. 6, at 15 (1967) (comparing Gini coefficients for United Kingdom, Denmark, West Germany, The Netherlands, Sweden, Norway, Finland, and France, during period from 1962 to 1964); Al-Samarrie \& Miller, State Differentials in Income Concentration, 57 AM. Econ. REv. 59, 63 (1967) (Gini coefficients for individual states in United States in 1959).

To measure the effect of taxation and of government expenditure on a nation's inequality, analysts have compared Gini coefficients calculated from the distribution of pre-tax incomes, the distribution of post-tax incomes, and the distribution of post-tax incomes augmented by the benefits of government expenditures. See, e.g., Conrad, supra note 39, at 200 (Gini coefficients in United States for pre-tax incomes, post-tax incomes, and post-tax incomes including government expenditures); Goldsmith, supra, at 271 (comparing Gini coefficients on before-tax incomes and after-tax incomes in United States).

Some economists have focused on the inequalities to be found within various occupational groups. See, e.g., id. at 276 (Gini coefficients calculated on after-tax incomes of laborers, of service workers, of craftsmen and operatives, of clerical and sales workers, of farmers and farm managers, of salaried proprietors, professionals, and technical workers, and of self-employed proprietors, professionals, and technical workers, in United States).

42. Economists using the Gini coefficient have measured inequality in the world's real consumption and have shown how little that inequality has diminished over time. See Beckerman \& Bacon, The International Distribution of Incomes, in UNFAsHIONABLE EcoNomics 62.63 (P. Streeten ed. 1970) (comparing Gini coefficients computed on distribution of world's real consumption in 1954-55 and 1962.63 and finding decline from .570 to .567 to be insignificant).

43. At least one economist has used the Gini coefficient to measure inequality in the distribution of wealth. See Yntema, supra note 39, at 429 (listing in Column R' $^{\prime}$ (for Gini's Ratio) Gini coefficients computed on distributions of males' assets in Australia, of females' assets in Australia, of wealth in United States, of estates in France, of estates in United Kingdom, of males' estates in Massachusetts, of males' estates in Wisconsin, and of males' estates in United States).

44. The Gini coefficient can be defined as follows:

$$
G=\left(1 / 2 n^{2} \bar{y}\right) \underset{i=1}{\sum_{j=1}^{n}} \sum_{j=1}^{n}\left|y_{1}-y_{1}\right|,
$$

where $n$ is the number of persons in the population, $y_{1}$ is the income of person $i, y_{1}$ is 
The Gini coefficient has a number of favorable characteristics that have been considered important for a measure of inequality. First, because the coefficient measures the difference between each person and everyone else in the population, it is a direct measure of income difference and hence of inequality. ${ }^{45} \mathrm{It}$ is thus able to capture a great deal of information about the distribution of income. Second, the Gini coefficient is sensitive to any shift in income between the poor and the rich; for example, it always registers an increase when income is transferred from a poorer person to a richer person within the population. ${ }^{46}$ Third, the value of the coefficient does not change even if the units measuring income are changed; ${ }^{47}$ consequently, the coefficient can make comparisons between different distributions of income regardless of the monetary units underlying those distribu-

the income of person $j$, and $\bar{y}$ is the mean income. A. SEN, ON ECONOMIC INEQUALITY 31 (1973); see Dalton, The Measurement of the Inequality of Incomes, 30 EcoN. J. 348, 353 (1920); Yntema, supra note 39 , at 425.

45. Sen, an economist, has written that, in general, a good measure of inequality should gauge the income difference between each person and everyone else. See A. SEN, supra note 44, at 28 (recommending comparison between every pair of incomes to "cap. ture everyone's income difference from everyone else").

The Gini coefficient meets this requirement. See id. at 31 ("Undoubtedly one appeal of the Gini coefficient . . . lies in the fact that it is a very direct measure of income difference, taking note of differences between every pair of incomes.") (emphasis in original). In contrast, other measures often take the difference between each income level and the mean, which might represent no particular person's income and which in any case can act only as a summary statistic for all the incomes in the population. See id. at 28 (criticizing one measure of inequality that captures difference of each income level from the mean only, "which might not be anybody's income whatsoever").

46. The economist Hugh Dalton maintains that a successful measure of inequality should be sensitive to transfers of income between a poorer person and a richer person within the population. See Dalton, supra note 44, at 351-52 (principle of transfers requires that transfer from richer to poorer diminish measure of inequality).

The Gini coefficient fulfills this requirement. See A. SEN, supra note 44, at 31 (Gini coefficient does not sacrifice "the quality of being sensitive to transfers from the rich to the poor at every level"); Dalton, supra note 44, at 353 (Gini coefficient "is perfectly sensitive to transfers'). The Gini coefficient can be defined by a formula equivalent to that stated above, see note 44 supra:

$$
\begin{gathered}
G=1+(1 / n)-\left(2 / n^{2} \bar{y}\right)\left[y_{1}+2 y_{2}+\ldots+n y_{n}\right], \\
\text { where } y_{1}>y_{2}>\ldots>y_{n} .
\end{gathered}
$$

A. SEN, supra note 44, at 31 . Since any term in the bracketed expression has a larger coefficient than a term to its left, a transfer from a poorer person to a richer person always decreases the bracketed expression. Because the sign in front of the bracketed expression is negative, the Gini coefficient always increases as a result of such a transfer.

47. The statistician Dwight Yntema states that a successful measure of inequality should not depend on the particular monetary units used to assess incomes. Yntema, supra note 39, at 423 ("An acceptable coefficient must be . . . independent of the unit in which income, or wealth, is measured.")

The Gini coefficient meets this condition. Id. at 423-25. Suppose, in the formula stated above, see note 44 supra, the units measuring income are changed so that incomes increase uniformly by the multiple $m$. Then both the numerator and the denominator $\left(2 n^{2} \bar{y}\right)$ increase by the multiple $m$, and the Gini coefficient remains the same. 
tions. Finally, the Gini coefficient is fairly easy to compute. ${ }^{18}$ On account of these attributes, the Gini coefficient has proven to be superior to other measures of inequality. ${ }^{48}$

The Gini coefficient is often given a graphical definition ${ }^{50}$ that is equivalent to its algebraic definition. ${ }^{51}$ This graphical definition can be modified so that the coefficient measures inequality in the coverage of retirement plans. The figure below illustrates how the

48. A fourth condition for a measure of inequality is that "[t]he numerical value of a coefficient should not be difficult to compute." Yntema, supra note 39, at 424 . The Gini coefficient satisfies this condition. Id. at 424-25.

49. See Nicholson, Redistribution of Income in the United Kingdom in 1959, 1957, and 1953, in INCOME AND WEALTh: SERIES X 121, 142 (C. Clark \& G. Stuvel eds. 1964) ("The best single measure of inequality in the distribution of income is probably the Gini coefficient.")

None of the measures competing with the Gini coefficient has all four of these char. acteristics. One competing measure is the relative mean deviation, which compares the income level of each person in the population with the mean income, sums the absolute values of all the differences, and divides by the total income of the population. A. SEN, supra note 44, at 25; see Yntema, supra note 39 , at 425 . The relative mean deviation is not very sensitive to shifts in income between rich and poor: it registers no change whatsoever when a transfer takes place between a poorer person and a richer person lying on the same side of the mean. See A. SEN, supra note 44, at 26-27.

Another measure, the variance, squares the differences between income levels and the mean income, sums all the squares, and divides by the total population. Id. at 27. The variance is sensitive to transfers taking place between all levels of income. Id. Values of the variance, however, depend upon the particular units that individuals in the population use to assess their incomes: by the definition of variance, if the monetary units are changed and incomes increase uniformly by the multiple $m$, the value of the variance increases by $\mathrm{m}^{2}$.

The coefficient of variations, which is the square root of the variance divided by the mean income, $i d$., does not depend on the particular units of income chosen by the population. By this definition, if the monetary units are changed and incomes increase by the multiple $m$, the coefficient of variation remains the same. The coefficient fails, however, to capture the income difference between each person and everyone else; instead, it measures the difference between each income level and the mean. See id. at 28.

The standard deviation of logarithms compares the logarithm of each income level with the logarithm of the mean, sums the squares of all the differences, divides by the total population, and takes the square root. Id. at 29; see Yntema, supra note 39, at 426. The standard deviation of logarithms suffers from two difficulties. First, it is insensitive to transfers over certain brackets of income. A. SEN, supra note 44, at 32 . Second, by concentrating solely on differences between the logarithms of income levels and the mean, the standard deviation of logarithms fails to measure income differences between each person and everyone else. Id. at 29 (standard deviation of logarithms "shares with [the variance] and [the coefficient of variation] the limitation of taking differences only from the mean").

Like the other measures that compete with it, the Gini coefficient satisfies two other conditions sometimes thought to be important: it is independent of the number of people in the population, and it has definite limits, 0 for equality and 1 for the greatest inequality. See Yntema, supra note 39, at 423-24.

50. See A. SEN, supra note 44 , at $\mathbf{3 0}$. By the graphical definition, the Gini coefficient is twice the area between a hypothetical line of strict equality and the actual cumulative distribution of the share of society's total income. See D. Palumbo, Statistics in Politicat ANd Behavioral Science 81 n.4 (1969).

51. See note 44 supra (stating algebraic definition). 
Gini coefficient could measure discrimination in a hypothetical retirement plan. For every data point, the percentile of employees by income is the $\mathrm{x}$-coordinate, and the percentage of all the plan's participants located in that percentile is the y-coordinate. The set of all data points, plotted and connected, forms the "Lorenz" curve for the plan. ${ }^{52}$

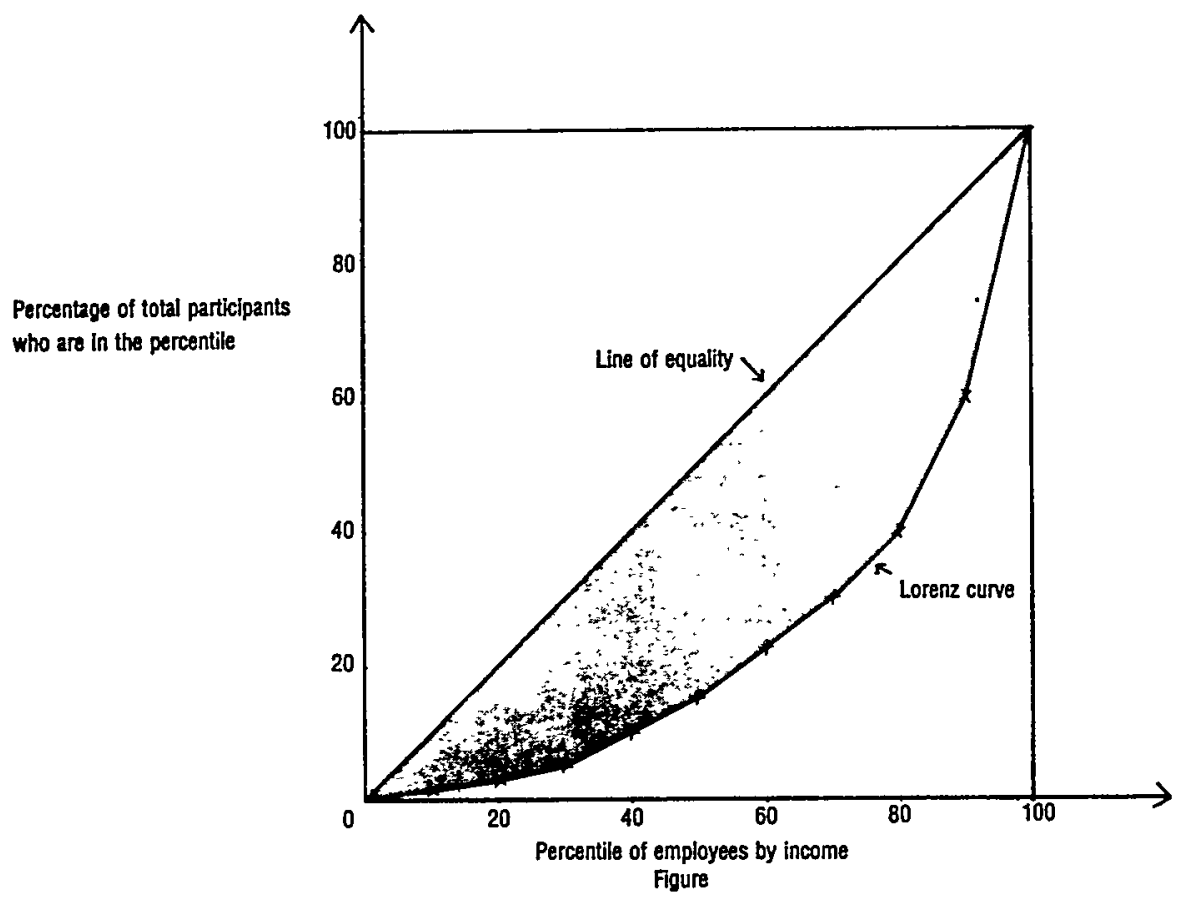

The Gini coefficient for the hypothetical plan is defined to be twice the area between the plan's Lorenz curve and a forty-five degree line. If a plan covered all classes of income proportionally, so that there was "strict equality" in coverage by income, ${ }^{53}$ any given proportion of workers by income would have an equivalent proportion of the plan's total coverage. The forty-five degree line, which consists of the points (q, q), represents this strict form of equality: along such a "line of equality," the lowest q percent of the workers enjoy precisely $q$ percent of the coverage available. The Gini coefficient

52. The statistician, M.O. Lorenz, introduced his curve in 1905. Lorenz, Methods of Measuring the Concentration of Wealth, 9 Publications AM. STatistical A. 209 (1905). It is a well-regarded statistical tool. See D. Palumbo, supra note 50, at 29 ("A particularly useful descriptive device is the Lorenz curve . . ...) Palumbo extended the concept of the Lorenz curve to observe inequality in political representation. Id. at 31-32.

53. See p. 822 supra. 
(twice the area between the plan's Lorenz curve and the line of equality) measures the extent to which the plan's Lorenz curve deviates from strict equality and is therefore a measure of inequality in coverage.

\section{Development of the Standard for Discriminatory Coverage}

Section $410(\mathrm{~b})(1)$ can be interpreted to disqualify a retirement plan when the plan's deviation from strict equality in coverage is intolerably high. ${ }^{54}$ The Gini coefficient is an appealing measure of a plan's deviation from equality in coverage and therefore could form the basis of a new test. To construct such a test, the IRS should determine a value of the Gini coefficient that would represent the maximum inequality in coverage that would be permitted. In evaluating a particular plan, the IRS would assemble data on the percentage of total participants in each decile of income, calculate the Gini coefficient for the plan by a simple formula, ${ }^{85}$ and approve the plan only if the coefficient is less than the specified maximum.

To develop an appropriate value for such a maximum, the IRS might adopt one of two strategies. Under the first, it would decide which of the agency's determinations, both reported decisions and

54. See pp. 819-22 supra.

55. If the plan's Lorenz curve is generated by data on each decile of income, the formula for the Gini coefficient turns out to be simply twice the sum of the areas of ten trapezoids. In the figure, let each of the points on the Lorenz curve be signified by $\left(x_{k}, y_{k}\right)$, where $k=0,1,2, \ldots, 10$, and $x_{k}$ takes on the value 0 when $k=0$ and multiples of ten thereafter. The region between the forty-five degree line (line of equality) and the Lorenz curve from $x_{\mathbf{k}}$ to $x_{\mathbf{x}+1}$ forms a trapezoid whose vertices are $\left(x_{k}, y_{k}\right),\left(x_{k}, x_{k}\right)$, $\left(x_{k+1}, x_{k+1}\right)$, and $\left(x_{k+1}, y_{k+1}\right)$. The area of the trapezoid is one-half the altitude times the sum of the bases:

$$
1 / 2\left(x_{x+1}-x_{x}\right)\left[\left(x_{x}-y_{x}\right)+\left(x_{x+1}-y_{x+1}\right)\right] .
$$

The area between the forty-five degree line and the Lorenz curve is the sum of the areas of all ten trapezoids:

$$
\sum_{k=0}^{9} 1 / 2\left(x_{x+1}-x_{k}\right)\left[\left(x_{k}-y_{k}\right)+\left(x_{k+1}-y_{x+1}\right)\right] \text {. }
$$

The Gini coefficient is defined to be twice the area between the forty-five degree line and the plan's Lorenz curve, see pp. 830-31 supra.

$$
G=\sum_{k=0}^{9}\left(x_{k+1}-x_{k}\right)\left[\left(x_{k}-y_{k}\right)+\left(x_{k+1}-y_{k+1}\right)\right] .
$$

Data on percentiles of income, rather than deciles, would yield a Gini coefficient that more accurately measures the plan's inequality in coverage. The formula, however, would require the summing of the areas of one hundred trapezoids, instead of just ten. Economists measuring inequality in income have traditionally used data on deciles to calculate Gini coefficients. See, e.g., United Nations Economic Commission for Europe, supra note 41, ch. 6, at 15; Beckerman \& Bacon, supra note 42, at 62. 
private rulings, ${ }^{56}$ reflect its soundest evaluations. It might, for example, choose the decisions issued in certain years or those made by certain district directors, as being the most exemplary. Alternatively, the IRS could generate a number of hypothetical plans and, in light of its experience, make determinations in each case. Then, calculating the Gini coefficient for each plan in this pool of either actual or hypothetical examples and noting the disposition in each case, the IRS could construct one frequency distribution of computed Gini coefficients for the rejected plans and another for the approved plans. ${ }^{57}$

The distributions would in all likelihood overlap because the vagueness of current tests lends itself to inconsistent decisionmaking. From the two distributions, the IRS should eliminate the most aberrant of the inconsistent decisions. To achieve this result, the IRS could consider overlapping cases to be inconsistencies and could strike from consideration the highest approved plan and the lowest rejected plan, then the next to the highest approved plan and the next to the lowest rejected plan, and so on, until the two remaining distributions overlapped at only one point. That point would represent the value that the IRS should adopt for its maximum Gini coefficient.

Under a second and simpler strategy, the IRS could generate a number of hypothetical plans and calculate the Gini coefficient for each plan. Then, by noting the value of the Gini coefficient corresponding to each plan in the pool, the IRS could estimate how much inequality was associated with each value of the Gini coefficient. After reviewing its ideas about the levels of inequality that are tolerable, the IRS could then specify a particular value of the Gini coefficient to be the maximum.

\section{An Extension to Discriminatory Vesting}

The new test, developed to limit inequality in coverage, could be adapted to the related problem of inequality in vesting. The interest of a participant in a plan is said to have vested when he acquires the right to receive his accrued benefits at retirement regardless of whether he is in the employer's service at retirement. ${ }^{.8}$ Section $411(\mathrm{~d})(\mathrm{l})$ of the Code disqualifies a plan if, as a result of the plan's vesting arrangement, "there have been, or there is reason to believe there will be, an accrual of benefits or forfeitures tending to dis-

56. The IRS makes determinations on at least 10,000 plans a year. See M. BERNstern, supra note 15 , at 185.

57. See Appendix, pp. 836-39 infra.

58. D. MCGILL, supra note 4, at 130 . 
criminate in favor of ... officers, shareholders, or highly compensated [employees]." "89

This section ensures that private plans supplement social security benefits for a broad segment of the labor force and guarantees equitable treatment for all participants in a plan. ${ }^{\circ 0}$ The Code, however, does permit a sponsoring company to deny vesting to employees by age or service requirements, ${ }^{61}$ which invariably lead to some deviation from equality in vesting across all income groups. ${ }^{62}$ Section $411(d)(1)$ should therefore be interpreted as setting a limit on a plan's deviation from strict equality in vesting rather than requiring strict equality. ${ }^{68}$

Under past revenue procedures, the IRS employed a numerical test: it granted a plan qualified status if the plan had so-called " $4 / 40$ vesting." 64 A plan with $4 / 40$ vesting provides for forty percent vesting after four years of service to the employer (that is, the participant has a nonforfeitable right to forty percent of the benefits accrued from employer contributions), forty-five percent vesting after five years of service, fifty percent vesting after six years, an additional ten percent vesting for each additional year of service, and full vesting after eleven years. ${ }^{65}$

Recently, however, the IRS decided that $4 / 40$ vesting does not further the goals of section 411 (d)(1) ${ }^{86}$ Under proposed regulations, the IRS would no longer ensure qualified status for a plan with $4 / 40$ vesting $^{67}$ and would institute a test of discrimination that relies on

59. I.R.C. $\S 411(\mathrm{~d})(\mathrm{l})(\mathrm{B})$.

60. See D. McGill, supra note 4, at 135 .

61. Under section $411(\mathrm{a})(2)(A)$ and section $411(\mathrm{a})(2)(B)$, classifications based upon years of service are permitted as long as specified percentages of accrued benefits are nonforfeitable after certain corresponding years of service (in section $411(\mathrm{a})(2)(\mathrm{A}), 100 \%$ must be nonforfeitable after 10 years; in section $411(\mathrm{a})(2)(\mathrm{B}), 25 \%$ must be nonforfeitable after five years, and progressively higher percentages nonforfeitable thereafter, until $100 \%$ is nonforfeitable after 15 years). Under section $411(a)(2)(C)$, classifications based on service and age combined are permissible, if specified percentages of accrued benefits are nonforfeitable for certain corresponding combinations of age and service. I.R.C. $\S 411$ (a)(2). Plans conforming to section 411(a)(2)(A), (B), or (C) must also fulfill the requirements of section $411(d)(1)$.

62. Employees who have not yet attained a specified age or who have worked less than a designated period of time tend to receive lower incomes than those who have not. See p. 821 supra.

63. See p. 822 supra.

64. See Rev. Proc. 76-11, 1976-1 C.B. 550, 550 ("[T] schedule of a plan as satisfying the [nondiscrimination] requirements of section 401(a)(4) of the Code ... [if the plan adopts] 4-40 vesting . . . ."); Rev. Proc. 75-49, 1975.2 C.B. 584, 585-86 (same).

65. Rev. Proc. 75-49, 1975-2 C.B. 584, 585-86.

66. See 45 Fed. Reg. 24,201, 24,201 (1980) (" $4 / 40$ vesting did not reflect the policies of ERISA [the Act containing section 411(d)(1)] if applied as a maximum vesting schedule.")

67. See 45 Fed. Reg. 39,869 , 39,870 (1980) (4/40 vesting should not be viewed as safe harbor). 
the facts and circumstances of each plan. ${ }^{08}$ According to this test, a "reasonable disparity between the vested benefits paid to or accrued by the prohibited group [that is, the officers, shareholders, and highly compensated employees] and the vested benefits paid to or accrued by other employees [would] ... not result in a finding that there is discriminatory vesting." 69

Illustrating the proposed test with several examples, ${ }^{70}$ the IRS indicated that it would give substance to the test in two ways. First, the IRS would compare the present value of the prohibited group's vested benefits with that of other employees' vested benefits. Second, after constructing a distribution, by income bracket, of employees who have vested benefits, the IRS would apply a cross-section test similar to the one it now uses to assess a plan's coverage.

The proposed test is vague ${ }^{71}$ and does not address inequality in vesting comprehensively. The general statement of the test and the first method of implementing it divide employees into only two groupsthe prohibited group and other employees-and thus are not sensitive to vesting by a variety of income classes. The second method of implementing the test, the cross-section approach, does not consider the total number of employees within each income class and hence cannot assess whether any class has a disproportionate share of the vesting available under the plan. ${ }^{72}$

68. Id. at 39,871 ("The determination of whether there is, or there is reason to believe there will be, discriminatory vesting shall be made on the basis of the facts and circumstances of each case.")

69. Id.

70. The first two examples are instructive. In the first example, a plan offers full vesting after 10 years of service and no vesting before that time. The present value of the vested benefits for officers and shareholders is less than the present value of the vested benefits of all other employees. The plan's vesting would not be considered discriminatory. Id. at $\mathbf{3 9 , 8 7 0}$.

In the second example, a plan again offers full vesting after 10 years of service and no vesting before that time. The distribution of vested employees by income meets the same type of cross-section test as that used to evaluate coverage. The plan's vesting would not be considered discriminatory. Id.

71. The IRS has failed to promulgate any standards for the general statement of the test or for either of the two methods of implementing the test. See id. at 39,870-71. Vagueness in the proposed tests for discrimination in vesting would generate the same types of costs that were generated by the vagueness of the coverage tests. See pp. 825-26 supra. The proposed tests would result in inconsistent decisions on discriminatory vesting, Interview with Chester Salkind, supra note 35; they would subject small companies to substantial costs of planning and negotiation, Interview with Paul Jackson, supra note 31; and they would generate significant planning costs for controlled groups, Interview with Attorney practicing in the field of retirement plans, supra note 24.

72. Like the cross-section test for coverage, the cross-section test for vesting does not consider the proportion of all vesting that each class receives, and the test does not compare that proportion with the proportion of all employees that the class contains. The test, therefore, cannot determine whether any class has a disproportionate share of the total vesting available under the plan. 
A new test based on the Gini coefficient could measure and limit inequality in vesting. To evaluate a particular plan, the IRS would count full vesting as one unit and partial vesting as an appropriate fraction of one unit. The total vesting available under the plan would be the sum of the units of vesting of every employee. The IRS would then assemble data presenting the proportion of total vesting given to each decile of employees, calculate the Gini coefficient for the plan, and approve the plan only if its coefficient were less than a specified maximum.

To determine the value of such a maximum, the IRS could adopt one of two strategies, similar to those suggested in the setting of discriminatory coverage. Under the first, the agency would make decisions on the qualification of numerous hypothetical plans, and then eliminate the aberrations from its two distributions of computed Gini coefficients until it arrived at an appropriate value for the maximum. The IRS, however, should not apply this procedure to actual past rulings: based on the obsolete 4/40 vesting rule, the agency's previous decisions on discriminatory vesting would be unreliable. Under the second strategy, the IRS would calculate the Gini coefficient for a number of hypothetical plans, estimate the level of inequality associated with the computed values of the coefficient, and choose a particular value of the coefficient to be the maximum.

\section{Conclusion}

The proposed test of discriminatory coverage has several advantages over the tests currently in use. Based on the Gini coefficient, the test would directly measure and limit inequality in coverage, substitute a single test for the present multiplicity of tests, and apply a clear numerical criterion. The proposed test would thus solve many of the problems besetting the current methods of judging discriminatory coverage. An additional advantage of the test is that, with minor adjustments, it could limit discrimination in a variety of related settings.

\section{APPENDIX}

This Appendix illustrates how to calculate the Gini coefficient for each plan in a particular pool of decisions reported to the public. Of the many public cases and rulings discussing retirement plans, only a few report the data needed to compute the Gini coefficient. ${ }^{73}$ In fact, public cases and

73. The formula for the Gini coefficient, see note 55 supra, requires data on the distributions of plan participants and excluded employees by income. 


\section{Retirement Plans}

rulings provide the necessary data on exactly fifteen retirement plans. ${ }^{74}$ Of these fifteen plans, fourteen were rejected and one was approved. ${ }^{75}$ The computed Gini coefficients for the fourteen rejected plans ranged from a high of .789 to a low of .120 , while the Gini coefficient. for the successful plan was .00758 . Table 1 below presents the fifteen plans in descending order of their Gini coefficients and gives, for each plan, the Gini coefficient, the final disposition of the plan, and the year of the disposition.

For purposes of this discussion, the same plan operating in different years is treated as a set of distinct plans, because each year the same plan covers a different number of employees in the various income brackets and is evaluated separately. Hence, in Table 1, Pulver Roofing Co. $v$. Commissioner, Parts I, II, III, and IV, represent the same plan operating in $1970,1971,1972$, and 1973 , respectively.

\section{Table 1}

$\begin{array}{llll}\text { Rulings and Cases } & \text { Gini Coefficients } & \text { Disposition } & \text { Year } \\ \text { 1. Pulver Roofing Co. v. Commissioner, } & & & \\ \text { Part I } & .789 & \text { rejected } & 1978 \\ \text { 2. King v. United States } & .751 & \text { rejected } & 1974 \\ \text { 3. Private Letter Rul. 7750008: Part II } & .714 & \text { rejected } & 1977 \\ \text { 4. Pulver Roofing Co. v. Commissioner, } & & & \\ \text { Part II } & .674 & \text { rejected } & 1978 \\ \text { 5. Rev. Rul. 69-398 } & .621 & \text { rejected } & 1969 \\ \text { 6. Pulver Roofing Co. v. Commissioner, } & & & \\ \text { Part IV } & .549 & \text { rejected } & 1978 \\ \text { 7. Wisconsin Nipple and Fabricating Corp. } & & & \\ \quad \text { v. Commissioner } & .533 & \text { rejected } & 1978 \\ \text { 8. Commissioner v. Pepsi-Cola Niagara } & & & \\ \text { Bottling Corp. } & .524 & \text { rejected } & 1968 \\ \text { 9. Private Letter Rul. 7750008, Part I } & .495 & \text { rejected } & 1977 \\ \text { 10. Liberty Machine Works, Inc. v. } & & & \\ \text { Commissioner, Part I } & .440 & \text { rejected } & 1974 \\ \text { 11. Pulver Roofing Co. v. Commissioner, } & & & \\ \text { Part III } & .360 & \text { rejected } & 1978 \\ \text { 12. Rev. Rul. 74-256 } & .242 & \text { rejected } & 1974 \\ \text { 15. Rev. Rul. 74-255 } & .130 & \text { rejected } & 1974 \\ \text { 14. Liberty Machine Works, Inc. v. Commissioner, } & & & \\ \text { 15. Rev. Rul. 70-200 } & .120 & \text { rejected } & 1974 \\ \text { 15. Rev. } & .00758 & \text { approved } & 1970\end{array}$

74. See Wisconsin Nipple \& Fabricating Corp. v. Commissioner, 581 F.2d 1235 (7th Cir. 1978); Commissioner v. Pepsi-Cola Niagara Bottling Corp., 399 F.2d 390 (2d Cir. 1968); King v. United States, 376 F. Supp. 1313 (D. Neb. 1974); Pulver Roofing Co. v. Commissioner, 70 T.C. 1001 (1978) (containing four plans with sufficient data); Liberty Mach. Works, Inc. v. Commissioner, 62 T.C. 621 (1974) (containing two plans with sufficient data); Rev. Rul. 74-256, 1974-1 C.B. 94; Rev. Rul. 74-255, 1974-1 C.B. 93; Rev. Rul. 70-200, 1970-1 C.B. 101; Rev. Rul. 69-398, 1969-2 C.B. 9; Private Letter Rul. 7750008 (1977) (containing two plans with sufficient data).

75. All of the plans in the cases and rulings listed above, see note 74 supra, were rejected except the plan in Rev. Rul. 70-200, 1970-1 C.B. 101, which was approved. 
Revenue Ruling 70-200 contains the plan that was approved, and $L i b$ erty Machine Works, Inc. v. Commissioner, Part II, contains the rejected plan with the lowest Gini coefficient. These important plans can be used to demonstrate the calculation of the Gini coefficient. The distributions of participants and excluded employees for the plan in Revenue Ruling 70-200 are presented above.70 The distributions for the plan in Liberty Machine Works, Inc. v. Commissioner, Part II, ${ }^{77}$ are shown in Table 2.

Table 2

Compensation Range
Over $\$ 50,000$
$\$ 25,001$ to $\$ 50,000$
$\$ 20,001$ to $\$ 25,000$
$\$ 15,001$ to $\$ 20,000$
$\$ 14,001$ to $\$ 15,000$
$\$ 13,001$ to $\$ 14,000$
$\$ 12,001$ to $\$ 13,000$
$\$ 11,001$ to $\$ 12,000$
$\$ 10,001$ to $\$ 11,000$
$\$ 9,001$ to $\$ 10,000$
$\$ 8,001$ to $\$ 9,000$
$\$ 7,001$ to $\$ 8,000$
$\$ 6,001$ to $\$ 7,000$
$\$ 5,001$ to $\$ 6,000$
$\$ 4,001$ to $\$ 5,000$
$\$ \$, 001$ to $\$ 4,000$
$\$ 2,001$ to $\$ 3,000$
$\$ 1$ to $\$ 2,000$
ToTAL

$\begin{array}{cc}\text { Excluded Employees } & \text { Participants } \\ 0 & 1 \\ 0 & 0 \\ 0 & 1 \\ 0 & 0 \\ 1 & 0 \\ 0 & 0 \\ 2 & 0 \\ 2 & 0 \\ 10 & 0 \\ 9 & 0 \\ 2 & 0 \\ 8 & 0 \\ 0 & 1 \\ 0 & 0 \\ 0 & 1 \\ 0 & 0 \\ 0 & 0 \\ 4 & 0 \\ 38 & 4\end{array}$

The Gini coefficient for each plan is computed in three steps. The first step is to determine the percentile that each income bracket of the plan represents. The second is to calculate the percentage of plan participants in each such percentile. The results can be assembled in tables as follows:

Rev. Rul. 70-200

Index of Percentile
$\mathbf{k}$
7
6
5
4
3
2
1
0

Percentile
$\boldsymbol{x}_{\boldsymbol{x}}$
$\mathbf{1 0 0 . 0}$
97.3
80.7
50.7
17.3
8.0
2.0
0.0

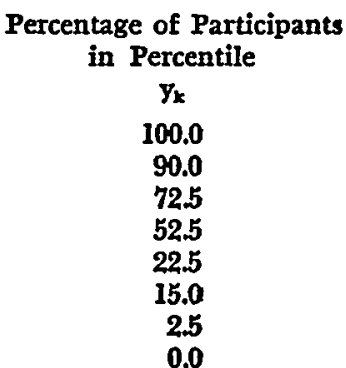

76. See note 28 supra.

77. Liberty Mach. Works, Inc. v. Commissioner, 62 T.C. 621,629 (1974) (distributions for 1969). 


\section{Retirement Plans}

Liberty Machine Works, Inc. v. Commissioner

Index of Percentile
$\mathbf{k}$
12
11
10
9
8
7
6
5
4
3
2
1
0

Percentile
$\mathrm{x}_{\mathbf{k}}$
$\mathbf{1 0 0 . 0}$
$\mathbf{9 7 . 6}$
$\mathbf{9 5 . 2}$
92.9
$\mathbf{8 8 . 1}$
$\mathbf{8 3 . 3}$
$\mathbf{5 9 . 5}$
$\mathbf{3 8 . 1}$
$\mathbf{3 3 . 3}$
14.3
11.9
9.5
0.0

Percentage of Participants in Percentile

$\mathbf{y}_{\mathbf{k}}$
$\mathbf{1 0 0 . 0}$
$\mathbf{7 5 . 0}$
$\mathbf{5 0 . 0}$
$\mathbf{5 0 . 0}$
$\mathbf{5 0 . 0}$
$\mathbf{5 0 . 0}$
$\mathbf{5 0 . 0}$
$\mathbf{5 0 . 0}$
$\mathbf{5 0 . 0}$
$\mathbf{5 0 . 0}$
$\mathbf{2 5 . 0}$
$\mathbf{0 . 0}$
$\mathbf{0 . 0}$

The third and final step is to apply the formula for the Gini coefficient to each plan:

$$
G=\sum_{k=0}^{b-1}\left(x_{k+1}-x_{k}\right)\left[\left(x_{k}-y_{k}\right)+\left(x_{k+1}-y_{k+1}\right)\right],
$$

where $b$ is the number of brackets of income that the sponsoring company has submitted in its application to the IRS. ${ }^{78}$ For the plan in Revenue Ruling 70-200, the result is .007575; for the plan in Liberty Machine Works, Inc. $v$. Commissioner, the result is .1199 .

78. See note 55 supra (deriving formula). 